\title{
A comparison between attachment styles and love styles in couples raised in divorce and normal families
}

\author{
Samira Shahovisi ${ }^{1}$, Mahmood Goodarzi ${ }^{2}$, Emad El-din Ezatpour $^{3}$ \\ 1-M.A in Clinical Psychology, Department of Psychology, Sanandaj Branch, Islamic Azad Univeristy, \\ Sanandaj, Iran. \\ 2- Assistant professor, Department of family counseling, Sanandaj Branch, Islamic Azad University, Sanandaj, \\ Iran (Corresponding Author). ORCID: 0000-0001-7376-9476 \\ E-mail:mg.sauc@gmail.com \\ 3- M.A in Clinical Psychology, Department of Psychology, Sanandaj Branch, Islamic Azad Univeristy, \\ Sanandaj, Iran. ORCID: 0000-0001-6440-028X
}

Received: 14/04/2019 Accepted: 23/09/2019

\begin{abstract}
Introduction: Attachment and love are the styles that have primary relationships in the family environment and are regarded as stable and multi-generational factors.

Aim: The purpose of this study was to determine the comparison between attachment styles and love styles in couples raised in divorce and normal families.

Method: The method of study was causal-comparative. From all couples who were living in Divandareh city, two groups of 50 Couples raised in a divorce family (25 females and 25 males) and 50 Couple raised in a normal family ( 25 females and 25 males) were selected through available sampling method. The Collins \& Reid's (1990) attachment Styles and the Hendrick \& Hendrik (1969) love styles Scale were used as tools of investigation. multivariate analysis of variance and Pearson correlation coefficient tests were used for analyzing data.
\end{abstract}

Results: The results showed that there are significant differences between attachment Styles and love style mean scores in couples raised in divorced and normal families. Generally, mean scores of Safe, avoidant attachment styles and showy, erotic love styles were higher in the couples raised in divorced families than the couples raised in normal families. While, couples raised in normal families gain-ed significantly higher scores in anxious attachment style, romantic, friendly and sacrificial love Styles in comparison to the couples raised in divorced families.

Conclusion: Attachment and love styles play an important role in the family stability and sustainability of this social institution, and this needs to be addressed in prenatal and divorce counseling centers.

Keywords: Attachment styles, Love styles, Families

\footnotetext{
How to cite this article : Shahovisi S, Goodarzi M, Ezatpour EE. A comparison between attachment styles and love styles in couples raised in divorce and normal families. Shenakht Journal of Psychology and Psychiatry. 2019; 6 (4): 80-89 .URL: http://shenakht.muk.ac.ir/article1-599-fa.pdf
}

Copyright $\odot 2018$ the Author (s). Published by Kurdistan University of Medical Sciences. This is an open access article distributed under the terms of the Creative Commons Attribution-Non Commercial License 4.0 (CCBY-NC), where it is permissible to download, share, remix, transform, and buildup the work provided it is properly cited. The work cannot be used commercially without permission from the journal. 


\title{
مقايسه بين سبكهاى دلبستغى و عشقورزى در زوجهاى بزرى شله در خانوادههاى طاق و عادى
}

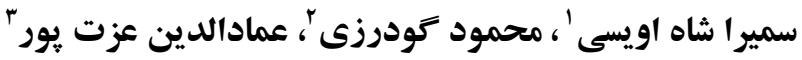

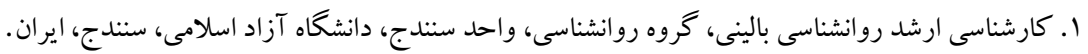

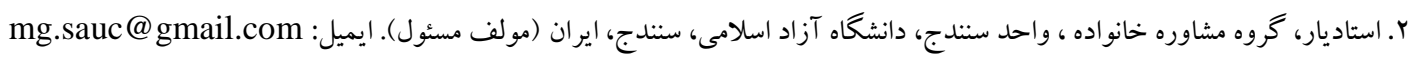 \\ r. كارشناسى ارشد روانشناسى بالينى، گروه روانشناسى، واحد سنندج، دانشگاه آزاد اسلامى، سنتدج، ايرهان.

مقدمه: دلبستَى و عشقورزى سبكهايى هستند كه بر روابط اوليه در محيط خانواده تأكيد داشته و بهعنوان عامل پايدار و جند نسلى تلقى مى شوند. هدف: مطالعه حاضر با هدف تعيين تفاوت سبك هاى دلبستى و عشقورزى در زوجهاى بزرگ شده در خانواده طلاق و عادى انجام كرديد. روش: مطالعه حاضر از نوع علّى - مقايسهاى بود. از بين جامعه آمارى يثزوهش حاضر كه شامل كليه زوجهاى ساكن شهر ديواندره

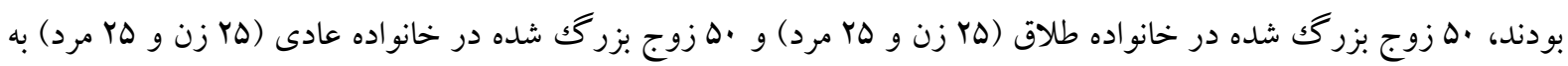
روش نمونه گيرى در دسترس به عنوان دو گروه مورد مطالعه انتخاب شدند. آزمون سبككهاى دلبستى كولينز و ريد ( •199) و مقياس سبككهاى عشقورزى هندريكك و هندريك (1999) به عنوان ابزارهاى جمع آورى اطلاعات بر روى آزمودنىها اجرا شد. براى تجزيهو تحليل دادهها از آزمون تحليل واريانس جند متغيره و آزمون ضريب همبستكى بيرسون استفاده گرديد. يافته ها: نتايج نشان داد كه بين ميانگين نمرات سبك هاى دلبستكى و عشقورزى در زوجهاى بزرك شده در خانو ادههاى طلاق و عادى تفاوت آمارى معنادارى وجود دارد. به طورى كه ميانگين نمرات زوجهاى بزرككشده در خانوادههاى طلاق در سبكهاى دلبستگى ايمن، اجتنابى و سبك هاى عشقورزى بازيخرانه و شهوانى بيشتر از زوجهاى بزرگك شده در خانو ادههاى عادى بود؛ اما ميانگين نمر ات زوجهاى بزر گكشده در خانوادههاى عادى در سبك دلبستگى اضطر ابى، سبكهاى عشقورزى رمانتيك، دوستانه و فداكارانه در مقايسه با زوجهاى بزرككشده در خانو ادههاى طلاق به طور معنادارى بيشتر بود. نتيجه گيرى: سبكىهاى دلبستىى و عشقورزى نقش مهمى در ثبات خانو اده و پيايدارى اين نهاد اجتماعى دارند و اين موضوع ايجاب مى كند در مراكز مشاوره بيش از ازدواج و طلاق توجه بيشترى به آن معطوف شود. كليدوازه: سبك هاى دلبستكى، سبكهاى عشقورزى، خانو اده 
به اعتقاد بالبى ( • •191) رفتارهاى دلبستخى ذاتى بوده و

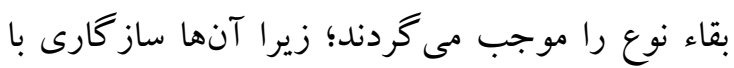

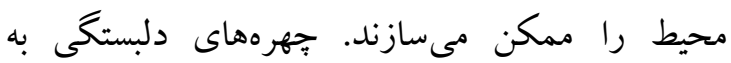

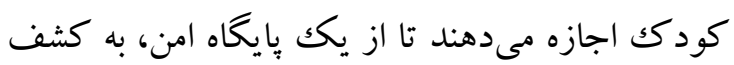
و جستجو بيردازد، در زمان مواجه با تهديدها امنيت كود كك را تأمين مى كنند و به او اجازه مى دهند تأ تنظيم سطوح استرس خود را ياد بخيرد. تصور مىشود كه

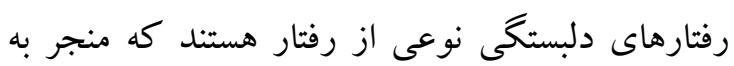

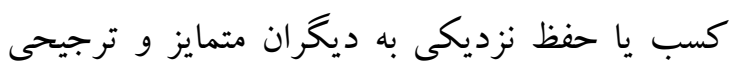

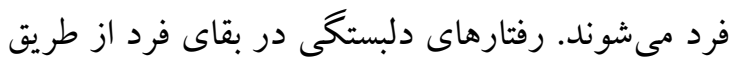
نكهداشتن او در تماس با مراقبان سهيم بوده و از اين

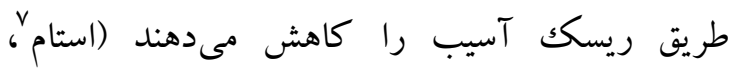
. ( $($. IV

بر اساس اين نظريه، سبك هاى دلبستخى مىتواند امن،

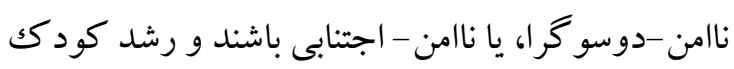
و توانايى برقرارى ارتباط در طول زندكى را تحت تأثير قرار دهند. در واقع اين سه سبك در بزرگكسالى نيز

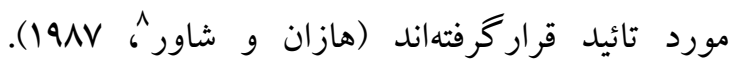

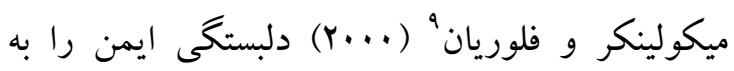
صورت يكك منبع درونى توصيف كردهاند كه مىتواند به شخص كمكك كند تا تجارب استرسزا را به صورت

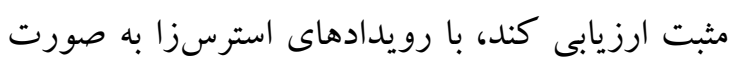

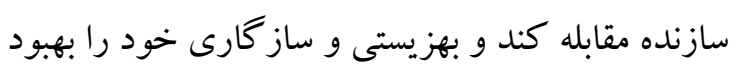
بخشد. افراد داراى سبك دلبستگى اجتنابى ديد كاه بدبينانه ترى نسبت به روابط، خودشان و ديخران داشته

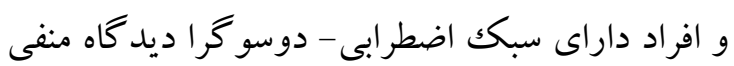

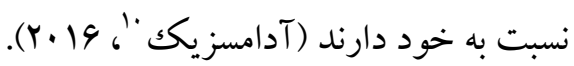
از مشهورترين إزوهشها در اين زمينه يُوهشهاى هازن و شاور (19AVV) و اينسورث (1991) است كه با برون

\footnotetext{
. Bowlby

7. Stamm

8. Hazan \& Shaver

9. Mikulincer \& Florian

10. Adamczyk
}

\section{مقلمه}

خانواده به لحاظ قدرت و از نظر گستردگى جهانشمولترين سازمان و يا نهاد اجتماعى است. اين امر نشان مىدهد كه خانواده واجد ارزش بقايى بسيار مهمى براى فرد و نوع انسان است (مظاهرى، حيدرى و يوراعتماد،

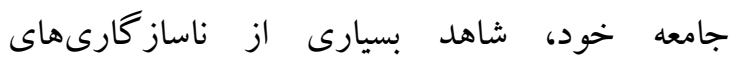

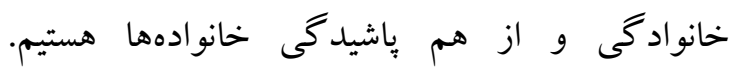
مهمترين عوامل ايجاد اين ناساز كارىها، عدم شناخت بـانت

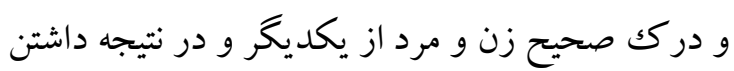
انتظارات و توقعات مبهم و غير واقعبينانه از يكديخر

$$
\text { است (ايزوراو كويه'، 19 19). }
$$

نظر به اهميت نقش خانواده در جامعه و تربيت و

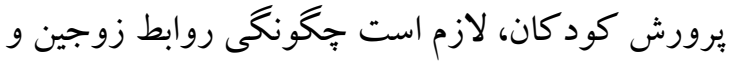

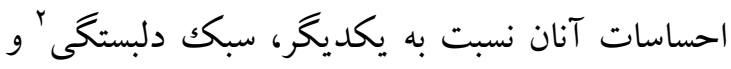
سبك عشقورزى 'َآنان مورد بررسى قرار گيرد. از جمله مفاهيمى كه رابطه بين والدين و فرزندان را به مرديه خوبى بيان مى كند، دلبستخى است. مفهوم دلبستخى

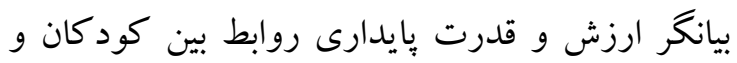

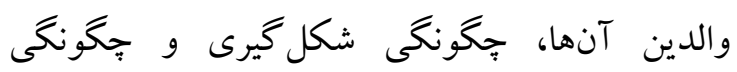
كيفيت اين روابط است كه مىتواند سلامت رشد

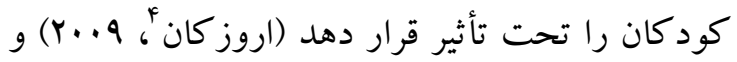

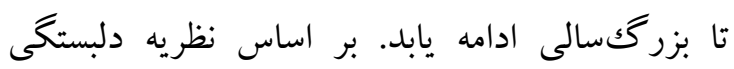

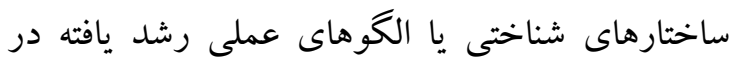

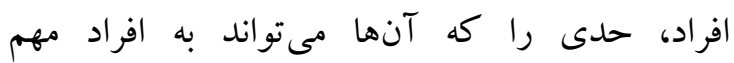
زندگىشان تكيه كنند را بازنمايى مى كند. به نظر مىرسد كه اين الكوهاى عمل، نقش حساسى را در

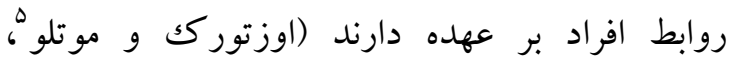

$(Y \cdot)$. 
كرفته است و صاحبنظران بسيارى به آن برداختهاند

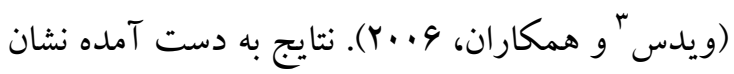
دادهاند كه عشق رابطه مستحكمى با رضايت زناشويى دارد و يكى از عوامل بسيار مهم در دستيابى به رضايت زناشويى عشق است. در همين راستا موراريو و و

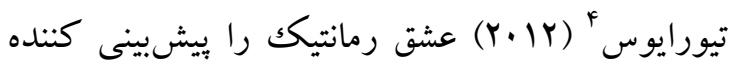
رضايتمندى زناشويى يافتند. با توجه به مطالب ذكر شده در اين يزوهش سبك يكهاى

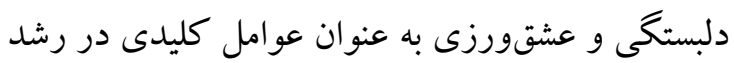
شناختى -عاطفى زوجهاى بزرگك شده در خانو ادههاى طلاق و عادى مقايسه شده است.

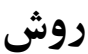
مطالعه حاضر از لحاظ هدف يك يُزوهش كاربردى و

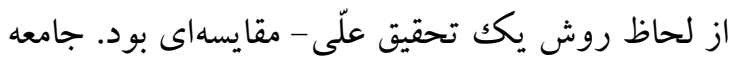
آمارى اين يُوهش شامل كليه زوجهاى ساكن

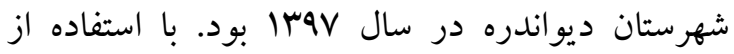

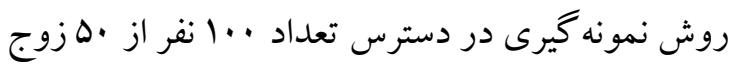

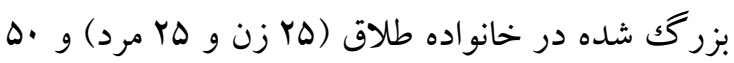
زوج بزرگك شده در خانو اده عادى (ه ز زن و ه r مرد) انتخاب شدند. مهمترين ملاككهاى ورود در اين يثوهش، مشاركت يكى از زوجين عادى يا طلاق در

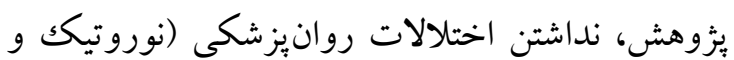
سايكو تيكs) و حداقل برخوردارى از سطح تحصيلات سيكل به شمار مىرفت و مهمترين ملاككهاى خروج

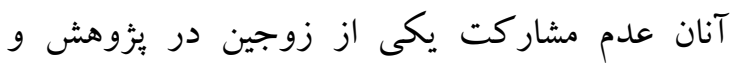
نداشتن حداقل سواد جهت تكميل برسشنامهها بود.

ابزار در اين يزوهش از ابزارهاى زير استفاده شده است:
الهام از نظريه بالبى در مورد ماهيت بيوندهاى عاطفى،

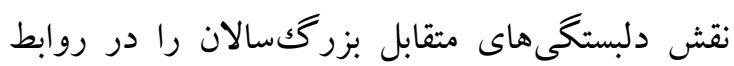
زوجها بررسى كردند. نتايج نشان داد كه مشخصههاى بيوند عاطفى بين زوجها با مشخصههاى بيوندهاى عاطفى كودك-مادر قابل مقايسه است و سبككهاى شناخته شده دلبستگى ايمن، اجتنابى و دو سوكرا، افكار و احساسات و رفتار آنان را در روابط زناشويى تحت تأثير قرار مىدهد (مالاج بينز '، هـ . (Y). عشق و سبككهاى عشقورزى عامل مؤثرى بر كيفيت روابط زناشويى است (حسينى و علوى، وهبا). عشق يكك حالت روانشناختى است كه طى سه دهه اخير مورد توجه روان شناسان اجتماعى واقع شده است و يزوهش هاى علمى در مورد تأثير آن بر زندكى صورت كرفته است. درباره ماهيت روان شناختى عشق و و تركيبات آن ديد كاههاى گوناكونى ارائه شده است.

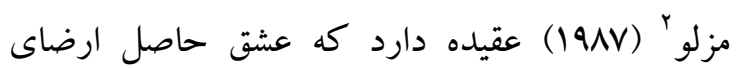
نيازهاى متقابل است. تا زمانى كه زوجها در كاسه

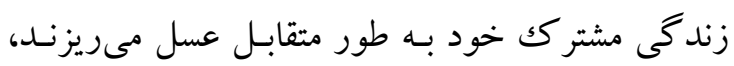
زندكى شيرين خواهـد شد. گلاسر و ويليام (.... عقيده دارند عشق فرآيندى است كه خود زوجها به وجود مى آورند. تا زمانى كه زوجها هر دو خود را را متعهد به ادامه رابطه بدانند و داراى اين اعتقاد باشند كه عشق جيزى است كه خودشان انتخاب كرده اند، رابطه عاشقانه ادامه خواهد يافت. يكى از مهمترين عوامل تعيين كننده يويايىهاى روابط زناشويى وجود عشق و كيفيت آن است (حفاظى طرقبه، فيروزآبادى و حقشناس، هیr|). از موارد مدنظر هر زوجى در ازدواج، داشتن رابطهى عاشقانه و

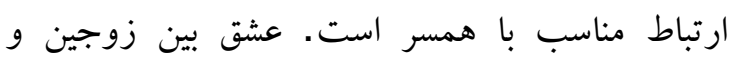
كيفيت آن در يزوهش هاى متعددى مورد مطالعه قرار

\footnotetext{
. Malach-Pines
}

. Maslow 
بنابراين، براى اين مقياس نمره كلى محاسبه نمىشود و هر فرد داراى 9 نمره در 9 خرده مقياس است. ساختار عاملى اين وبرسشنامه در جامعه ايرانى توسط

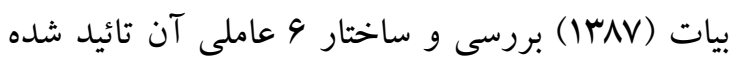
است. هندريكك و هندريك ضريب همسانى درونى اين

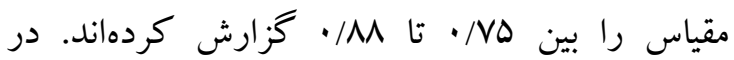
يثوهش حاضر يايايى خرده مقياسهاى اين آزمون با

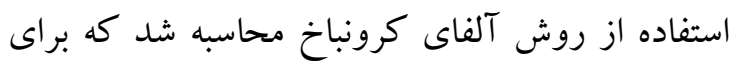
خرده مقياسهاى عشق فداكارانه 94/، بازيخرانه VV/

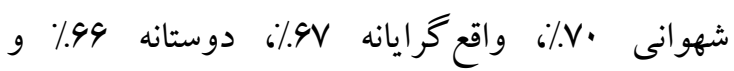
رمانتيك VV٪ استفاده گرديد.

شيوه اجراى ئزوهش حاضر به صورت انفرادى و در محل سكونت آزمودنىها بود، به طورى كه بعد از دسترسى به نمونه تحقيق و برقرارى ارتباط با آن ها، برسش نامههاى سبك هاى دلبستخى و عشقورزى در اختيار آزمودنىها قرار گرفت تا با مطالعه آن ها به به

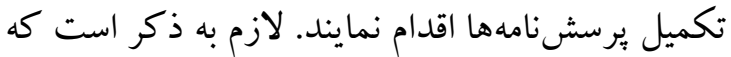

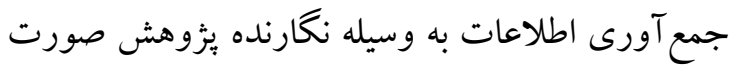
كرفت.

سر انجام دادههاى جمع آورى شده مورد تجزيه و تحليل آمارى قرار گرفتند. براى تجزيه و تحليل آمارى علاوه بر استفاده از آزمونهاى آمار توصيفى نظير فراوانى،

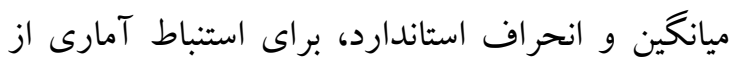
آزمون آمارى تحليل واريانس جندمتغيره استفاده شد. ضمناً جهت رعايت بيش فرض آمارى نهاى آزمون تحليل

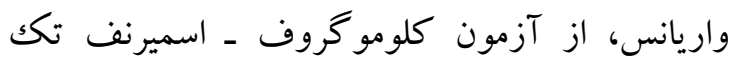
نمونه اى براى فرض نرمال بودن جامعه آمارى، آزمون

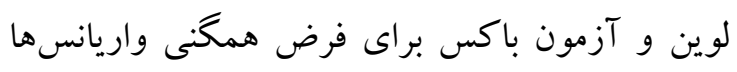

استفاده شد.

يافتهها
يرسشنامه سبك هاى دلبستغى': اين مقياس ابتدا توسط

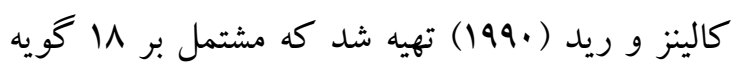

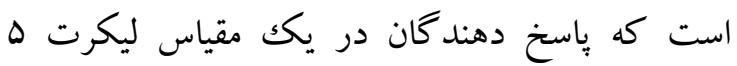
درجهاى ميزان موافقت يا مخالفت خود با هر يك از عبارات را بيان مى كنند. آزمودنىها بر اساس نتايج بهدست آمده در يكى از سه گروه داراى سبك بـ

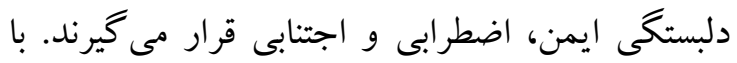

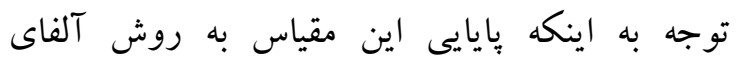

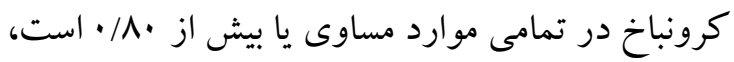
آزمون از اعتبار بالايى برخورد دار است. از سوى ديخر

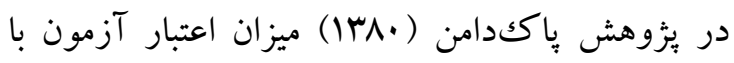
استفاده از آزمون مجدد بهصورت همبستخى بين اين دو اجرا مشخص شده است. اين يرسشنامه در مورد ..1 دختر و بسر كلاس دو دبيرستان كه بهصورت تصادفى

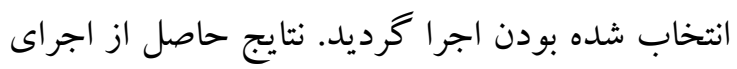
دوباره اين برسشنامه با فاصله زمانى يكك ماه از يكديخر بيانگر آن بود كه اين آزمون در سطح هه/. داراى اعتبار

يرسشنامه سبكهاى عشقوززى: مقياس سبككهاى عشقورزى توسط هندريك و هندريك (1919) از (194) يرسشنامه سبكهاى عشقورزى لى (19VY) استخراج

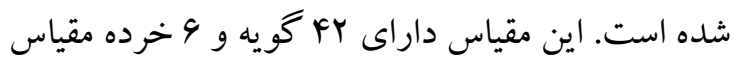
است و هر خرده مقياس داراى V ماده است. اين مقياس شش حالت عشق اروس (عشق احساساتى)، لودوس

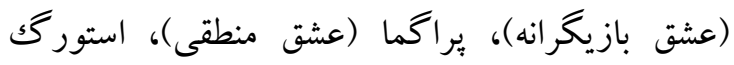

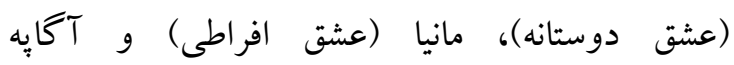

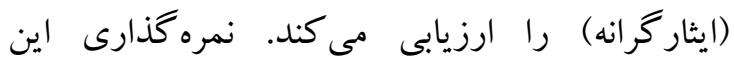

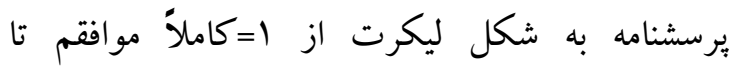

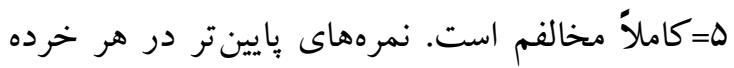

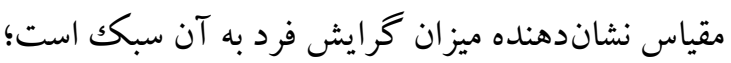

'. RAAS 
از لحاظ ميزان تحصيلات بيشتر آنان در سطح ابتدايى

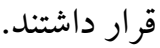

يافتهاى جمعيت شناختى مطالعه نشان داد FF د درصد از

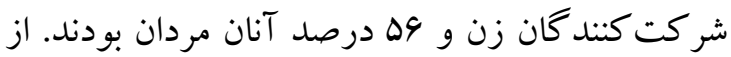
نظر سنى بيشتر آزمودنى ها در دامنه بين צY تا ·r سال و

جدول ا شاخصهاى توصيفى نمرات برسشنامه سبك هاى دلبستكى در دو كروه

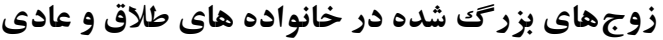

\begin{tabular}{|c|c|c|c|c|c|}
\hline حداكثر & حداقل & انحر اف استاندارد & ميانغين & كروه & سبك \\
\hline rr & ir & $r / \Delta$ & $19 / V$ & زوجهاى بزرگك شده در خانو اده طلاق & \multirow[t]{2}{*}{ سبك دلبستغى ايمن } \\
\hline rr & 1. & $r / \Lambda$ & $10 / 1$ & زوجهاى بزرگك شده در خانواده عادى & \\
\hline rI & ir & $1 / 9$ & $|V /|$ & زوجهاى بزر گك شده در خانو اده طلاق & \multirow[t]{2}{*}{ سبك دلبستكى اجتنابى } \\
\hline rF & 1. & $r / 9$ & $19 / 0$ & زوجهاى بزرگك شده در خانو اده عادى & \\
\hline rI & 11 & $r / 9$ & $10 / 9$ & زوجهاى بزر گك شده در خانو اده طلاق & \multirow[t]{2}{*}{ سبك دلبستغى اضطر ابى } \\
\hline ro & 1. & $r / 9$ & $1 \wedge / 1$ & زوجهاى بزرگك شده در خانو اده عادى & \\
\hline
\end{tabular}

و ميانگين سبك دلبستخى اضطرابى در زوجهاى

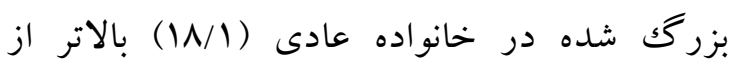
زوج هاى بزرگك شده در خانو اده طلاق (1ه/9) است.
نتايج جدول ا نشانگر آن است كه بهطور كلى

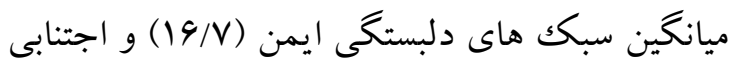
(IV/I) بالاتر از زوجهاى بزركى شده در خانو اده عادى است

جدول r شاخصهاى توصيفى نمرات يرسشنامه سبك هاى عشق ورزى در دو كروه

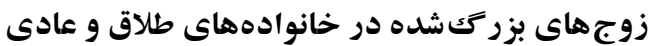

\begin{tabular}{|c|c|c|c|c|c|}
\hline 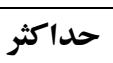 & حداقل & انحر اف استاندارد & ميانكين & كروه & سبكى \\
\hline 19 & f & $r / 9$ & $11 / 2$ & زوجهاى بزرگك شده در خانواده طلاق & \multirow{2}{*}{ سبك عشقورزى رمانتيكى } \\
\hline 19 & $\wedge$ & $r / r$ & $\mid r / \Lambda$ & زوجهاى بزرگك شده در خانواده عادى & \\
\hline 19 & 9 & $r / F$ & $11 / 9$ & زوجهاى بزرگك شده در خانواده طلاق & \multirow[t]{2}{*}{ سبك عشقورزى بازيكر انه } \\
\hline 19 & v & $r / r$ & $11 / 1$ & زوجهاى بزرگك شده در خانو اده عادى & \\
\hline 19 & 9 & $r / \Lambda$ & 11 & زوجهاى بزرگك شده در خانواده طلاق & \multirow[t]{2}{*}{ سبكى عشقورزى دوستانه } \\
\hline 19 & 4 & $r / \Lambda$ & $\mid r / F$ & زوجهاى بزرك شده در خانو اده عادى & \\
\hline 19 & v & $1 / 9$ & $I Y / Y$ & زوجهاى بزرگك شده در خانواده طلاق & \multirow{2}{*}{ سبك عشقورزى واقع } \\
\hline 19 & 9 & $1 / 9$ & $M / Y$ & زوجهاى بزرگك شده در خانو اده عادى & \\
\hline 19 & v & $r / f$ & ir & زوجهاى بزرگك شده در خانواده طلاق & \multirow[t]{2}{*}{ سبك عشقورزى شهوانى } \\
\hline 10 & v & $r / r$ & $11 / \mathrm{V}$ & زوجهاى بزرگك شده در خانو اده عادى & \\
\hline 19 & v & $r / \Gamma$ & 1. & زوجهاى بزرگك شده در خانواده طلاق & \multirow[t]{2}{*}{ سبك عشقورزى فداكارانه } \\
\hline 19 & 9 & $r / \Delta$ & $11 / V$ & زوجهاى بزرگك شده در خانو اده عادى & \\
\hline
\end{tabular}

دوستانه (I/F/F) و فداكارانه (I/V) در زوجهاى بزرگ شده در خانواده عادى بالاتر از زوجهاى
نتايج جدول Y نشانكر آن است كه بهطور كلى ميانگين سبكهاى عشقورزى رمانتيك ( (I/)، 


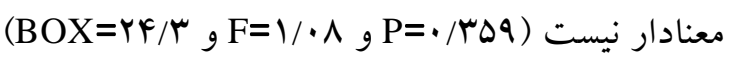
و در نتيجه بيشفرض تفاوت بين كواريانسها برقرار

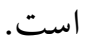
همجِين با بررسى آزمون معنادارى تحليل واريانس جندمتغيرى (كل) بر روى نمر ات سبك هاى دلبستگى و عشقورزى، نتايج نشان داد سطوح معنادارى همه آزمونها (اثر بيلايى، لامبدا ويلكز، اثر هتلينگك و بزرگكترين ريشه خط) قابليت استفاده از تحليل واريانس جندمتغيرى را مجاز مىشمارد. بدين كونه در گروههاى مورد مطالعه حداقل از نظر يكى از متغيرهاى وابسته تفاوت معنادارى وجود دارد.
بزرگك شده در خانو اده طلاق است و ميانكين سبك هاى عشق ورزى بازيخر انه (1/4) و شهوانى (Y (I) در زوجهاى بزرگكشده در خانواده طلاق بالاتر از زو جهاى بزرگك شده در خانواده عادى است. جهت بررسى همسانى واريانس ها بين متغيرهاى مورد مطالعه از آزمون لوين استفاده شد و نتايج نشان داد سطح آماره (F) براى هيج يكك از مؤلفههاى مـورد مطالعه در يـزّوهش حساضر معنا دار نيست (ه) - P> (P) و اين نشاندهنده آن است كه واريانس خطاى اين متغيرها در بين آزمودنىها (خانواده طلاق و عادى) متفاوت نيست و واريانس ها با هم برابرند. براى بررسى فرض همخنى كواريانسها از آزمون باكس استفاده شد و نتايج نشان داد كه مقدار باكس

\begin{tabular}{|c|c|c|c|c|c|}
\hline سطح معنىدارى & $\mathbf{F}$ & ميانكين مجذورات & درجه آزادى & مجموع مجذورات & متغير \\
\hline.$/ 19$ & $\Delta / 9$ & $\mathrm{Mr} / \mathrm{g}$ & 1 & $M / 9$ & سبك رمانتيكى \\
\hline - /YFA & $1 / r$ & $V / r$ & 1 & $V / r$ & سبك بازيكر انه \\
\hline.$/ \cdot 11$ & $9 / \mathrm{V}$ & $\Delta F / V$ & 1 & $\Delta F / V$ & سبك دوستانه \\
\hline$\cdot / 909$ & $\cdot /$ &.$/ \cdot 1$ & 1 & $\cdot / \cdot 1$ & سبك واقع كرايانه \\
\hline - / Far & $\cdot / f$ & $r / \Delta$ & 1 & $r / \Delta$ & سبك شهوانى \\
\hline$\cdot / \cdots \Delta$ & $\Lambda / 1$ & $V Y / r$ & 1 & $V Y / Y$ & سبك فداكارانه \\
\hline$\cdot / \cdot v^{\mu}$ & $r / r$ & YF & 1 & YF & سبك ايمن \\
\hline$\cdot / I V F$ & $1 / \wedge$ & $1 \cdot / r$ & 1 & $1 \cdot / r$ & سبك اجتنابى \\
\hline$\cdot / \cdots 1$ & $1 \cdot / V$ & $11 / / A$ & 1 & $11 \mathrm{~N} / \mathrm{A}$ & سبك اضطر ابى \\
\hline
\end{tabular}

دلبستكى ايمن و سبك دلبستگى اجتنابى تفاوت معنادارى وجود ندارد (1 • • (p). هدف مطالعه حاضر مقايسه سبككهاى دلبستكى و عشق ورزى در زوجهاى بزرگك شده در خانو ادههاى طلاق و عادى بود. نتايج اين بيزوهش نشان داد كه بين سبك دلبستگى در ميان زوجهاى بزرك شده در خانو ادههاى طلاق و عادى تفاوت معنادارى وجود دارد. به اين
نتايج جدول ب نشان مىدهد كه بين سبك عشق ورزى

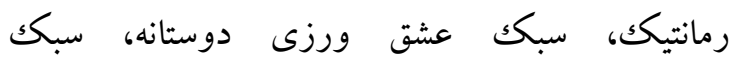
عشقورزى فداكارانه و سبك دلبستخى اضطرابى در ميان زوجهاى بزرگك شده در خانوادههاى طلاق و عادى تفاوت معنادارى وجود دارد ( ( • p)؛ اما بين زوجهاى بزرك شده در خانوادههاى طلاق و عادى از لحاظ سبك عشق ورزى بازيكر انه، سبك عشق ورزى واقع گرايانه، سبكك عشق ورزى شهوانى، سبك 
از ديخر نتايج اين بزوهش اين بود كه بين سبكهاى عشقورزى رمانتيك، دوستانه و فداكارانه در ميان زوجهاى بزرگك شده در خانوادههاى طلاق و عادى تفاوت معنادارى وجود دارد. به اين صورت كور كه ميانكين سبكك هاى عشقورزى رمانتيك، دوستانه و فداكارانه در

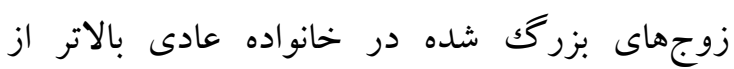
زوجهاى بزرگك شده در خانواده طلاق است اما بران ميانگين سبككهاى عشقورزى بازيگرانه و شهوانى در برد

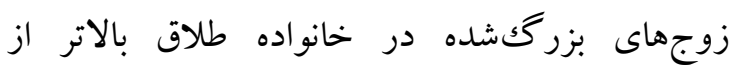

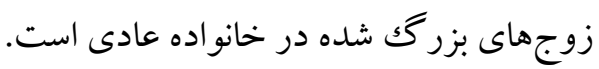
يافتهاى اين بثزوهش با يافتهاى تحقيقات هدايتى دانا

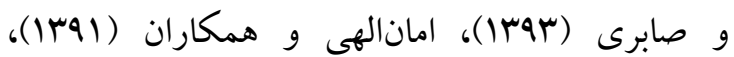

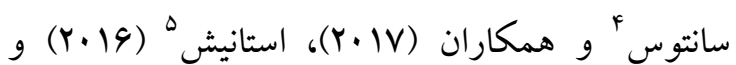

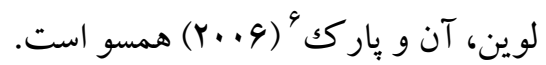
در تبيين اين يافته مىتوان كفت عشق و روابط عاشقانه، جزئى لاينفك از ذهن و زندكى بشر امروز است. لذا براى داشتن رابطه سالم، صميميت از اهميت بسزيى ليى لهرتي برخوردار است. وقتى احساسات نزديك هيجانى و محبت بين همسران ابراز مىشود، با افزايش زمان باهم

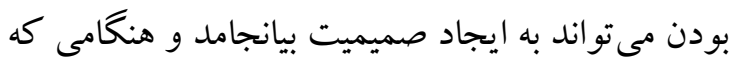
صميميت در رابطه وجود دارد، رابطه تقويت مى گردد. اما زمانى كه ارتباط به صورت تدافعى، سرد و و بىاحساس باشد، رابطه تضعيف مى گردد. نتايج يخوهش هدايتى دانا و صابرى (YMTI) نشان داد كه از ميان عشق و سبككهاى آن مؤلفههاى صميميت و تعهد بيشترين سهم را در رضايت زناشويى داشتند اما متغير ميل (شور و شوق) بيش بينى معنادارى براى رضايت

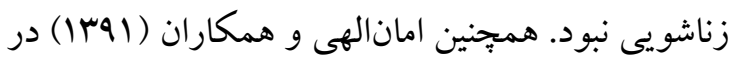

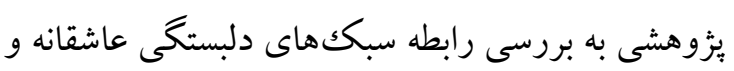
سبككهاى عشق با رضايت زناشويى در كاركنان زن بر رلن
صورت كه ميانگين سبك هاى دلبستگى ايمن و اجتنابى در زوجهاى بزرگك شده در خانواده طلاق بالاتر از زوجهاى بزرگك شده در خانو اده عادى است. با نگاهى به ادبيات يزوهش ملاحظه مى كردد كه اين يافته با نتايج يزوهش هاى متعددى همجيون امان الهى و

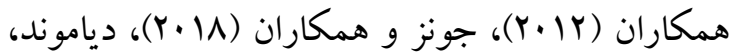

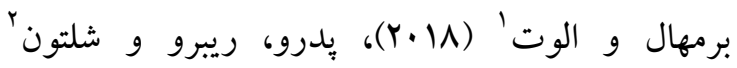

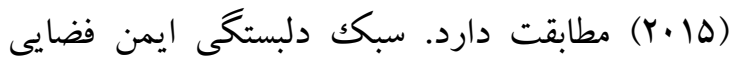
مطمئن همراه با امنيت را براى افراد ايجاد مى كند كه در آن به تعامل بيردازند و همجِين از طرفى ديخر كار كرد

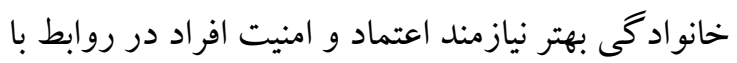
همديخر است. افراد با سبكك دلبستخى ايمن مى توانند هم در نقشهاى ولى- فرزندى و هم در ارتباطات و همر كاهش تعارضات خانوادگى و هم در ساير ابعاد

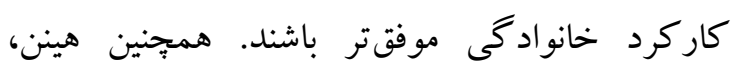

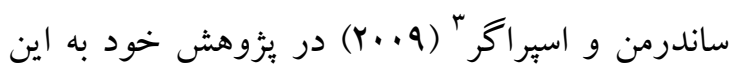
نتيجه رسيدند كه روابط و تجربيات اوليه به شكل دلبستگى بر تجربيات زندگى بعدى تأثير مى گذارد. اين

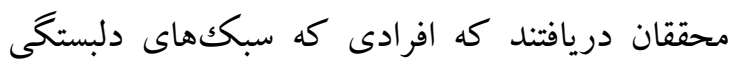
ناايمن (اجتنابى و اضطرابى) داشتند، ميزان بالايى از طرد توسط والدين، ميزان يايينى از حمايت خانوادگى ليقى

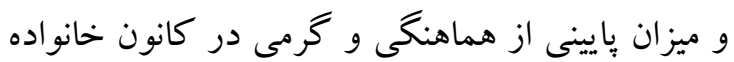

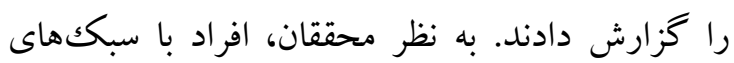
دلبستكى نايمن در خانو ادههايى با مشكلات كاركردى

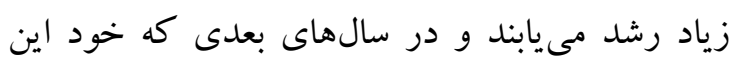

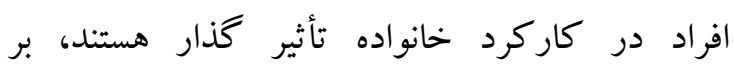
مشكلات كاركردى دامن مىزنند و نه تنها تأثيرى مثبت در فرايند كاركرد خانواده ايجاد نمى كنند، بلكه بر تنوع و دامنه مشكلات خانو اده اضافه مى كنند.

\footnotetext{
1. Diamond, Brimhall \& Elliott

. Pedro, Ribeiro \& Shelton

. Hinnen, Sanderman \& Sprangers
} 
Amanelahi A, Aslani K, Tashakor H, Ghavabesh S, Nekoei S. (2012). Romantic Attachment/Love Styles and Marital Satisfaction in Women: Investigating the Relationship. Women's Studies Sociological and Psychological, 10(3), 67-86. [In Persian].

Bowlby J. (1980). Loss: Sadness and depression. Attachment and loss, Vol. 3.

Diamond RM, Brimhall AS, \& Elliott M. (2018). Attachment and relationship satisfaction among first mamied, remarried, and post-divorce relationships. Joumal of Family Therapy, 40, S111-S127.

Erozkan A. (2009). The relationship between attachment styles and social anxiety: An investigation with Turkish university students. Social Behavior and Personality: an intermational joumal, 37(6), 835-844.

William G. (2000). Counseling with Choice Theory, The New Reality Therapy.

Hedayati dana S, \& Sabri H. (2014). Predicting Marital Satisfaction Based on Love Styles (Intimacy, Desire, Commitment) and Anxiety. Family Studies, 40, 527-511. [In Persian]

Hefazi Torqabeh M, Firouz Abadi A, \& Haqshenas H. (2006). Relations between love styles and marital satisfaction. Joumal of Mazandaran University of Medical Sciences, 16(54), 99109. [InPersian]

Hazan C, \& Shaver PR. (1987). Romantic love conceptualized as an attachment process. Journal of personality and social psychology, 52(51), 1-524.

Hinnen C, Sanderman R, \& Sprangers MA. (2009). Adult attachment as mediator between recollections of childhood and satisfaction with life. Clinical Psychology \& Psychotherapy: An International Joumal of Theory \& Practice, 16(1), 10-21.

Hosseini F, Alavi Langeroodi S. (2017). The role of attachment styles and marital satisfaction on sexual satisfaction through the mediation of love among married. Women's Studies Sociological and Psychological, 15(3), 165188. [InPersian]

Izuhara M, \& Koppe S. (2019). Inheritance and family conflicts: exploring asset transfers

$$
\begin{aligned}
& \text { متأهل يرداختند. نتايج نشان مىدهد كه سبك دلبستخى }
\end{aligned}
$$

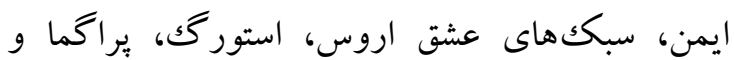

$$
\begin{aligned}
& \text { اخيب با رضايت زناشويى رابطه مثبت دارند. سبككهاى }
\end{aligned}
$$

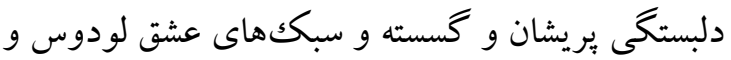

$$
\begin{aligned}
& \text { مانيا با رضايت زناشويى رابطه منفى دارند. }
\end{aligned}
$$

$$
\text { نتيجه تيرى }
$$

با توجه به اين كه سبكهاى دلبستخى و سبككهاى عشقورزى وابسته به فرهنگ و ارزشهاى مذهبى در هر جامعهاى است لذا لازم است جنين يزوهش هايى در ساير جوامع اجرا شود تا بتوان با اعتماد و اطمينان بيشترى به نتايج حاصله استناد كرد. ازجمله محدوديتهاى بزظوهش مى توان به عدم دسترسى راحت به زوجهاى بزرگك شده در خانواده طلاق و همجنين يكى بك دست نبودن آزمودنى ها از لحاظ سن، جنس و تحصيلات اشاره كرد.

در راستاى نتايج اين تحقيق بيشنهاد مى شود كه با بركزارى جلسات و كار گاههاى آموزشى بتوان زمينه را براى ازدواج يايدار فراهم نمود. لذا مسئولان امر

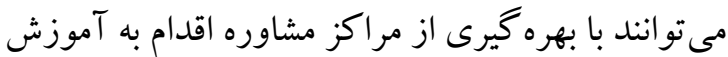
صحيح زوجين جهت كاهش مشكلات آنان نمايند و الخوهاى درست با هدف توقف رشد نرخ طلاق ارائه دهند.

\section{سياسگزارى}

$$
\begin{aligned}
& \text { بدينوسيله از كار كنان اداره بهزيستى و عوامل اجرايى } \\
& \text { مركز مشاوره آواى سلامت شهرستان ديواندره كه با ما لمانسئ } \\
& \text { كمال همكارى را داشتند، تشكر مىنماييم. }
\end{aligned}
$$

\section{References}

Adamczyk M. (2016). Attachment styles and adolescent's psychosocial functioning-case studies. Psychoterapia, (3), 89-102. 
shaping intergenerational relations. Families, Relationships and Societies, 8(1), 53-72.

Jones JD, Fraley RC, Ehrlich KB, Stem JA, Lejuez

CW, Shaver PR, \& Cassidy J. (2018).

Stability of attachment style in adolescence:

An empirical test of altemative developmental processes. Child development, 89(3), 871-880.

Levine TR, Aune KS, \& Park HS. (2006). Love styles and communication in relationships: Partner preferences, initiation, and intensification. Communication Quarterly, 54(4), 465-486.

Malach-Pines A. (2005). Falling in Love-why We Choose the Lovers We Choose. Taylor \& Francis Limited.

Maslow A. (1987). Motivation and Personality (A. Rezvani Trans.). Mashhad: Astan Quds Razavi [in Persian].

Mazaheri M, Haydari M, \& Pour Etemad H. (2005). Comparison of Mental Health in Student Marriage Couples and Normal Couples. Psychology Journal, 7(1), 36-49. [In Persian]

Mikulincer M, \& Florian V. (2000). Exploring individual differences in reactions to mortality salience: Does attachment style regulate terror management mechanisms?. Journal of personality and social psychology, 79(2), 260.

Muraru AA, \& Turliuc MN. (2012). Family-oforigin, romantic attachment, and marital adjustment: a path analysis model. ProcediaSocial and Behavioral Sciences, 33, 90-94.

Ozturk A, \& Mutlu T. (2010). The relationship between attachment style, subjective wellbeing, happiness and social anxiety among university students'. Procedia-Social and Behavioral Sciences, 9, 1772-1776.

Pedro MF, Ribeiro T, \& Shelton KH. (2015). Romantic attachment and family functioning: The mediating role of marital satisfaction. Journal of Child and Family Studies, 24(11), 3482-3495.

Santos S, Crespo C, Canavarro MC, \& Kazak AE. (2017). Parents' romantic attachment predicts family ritual meaning and family cohesion among parents and their children with cancer. Joumal of pediatric psychology, 42(1), 114-124.
Stamm BM. (2017). Developmental theory joining depth psychological theory: From disupted attachment to ensouled living. Pacifica Graduate Institute.

Stanish NA. (2016). Family structures as predictors of attachment security: The relationship between parental attachment security and romantic attachment security in stepfamilies and intact families (Doctoral dissertation, Purdue University).

Vedes A, Hilpert P, Nussbeck FW, Randall AK, Bodenmann G, \& Lind WR. (2016). Love styles, coping, and relationship satisfaction: A dyadic approach. Personal Relationships, 23(1), 84-97. 